ISSN 2079-3871

\title{
From Juke Joints to Jazz Jams: The Political Economy of Female Club Owners
}

\author{
Kara Attrep \\ Northern Arizona University \\ Kara.Attrep@nau.edu
}

\begin{abstract}
The history of jazz and blues is tied up with the spaces owned and curated by female proprietors. Early jazz making was supported by enterprising women who would host lawn parties at their residences in New Orleans. The blues developed in places known as juke joints, which were and are still often women-owned spaces in the southern United States. Nevertheless, while histories of jazz and blues tend to focus on the musicians and composers of the respective genres, the venues have largely gone unstudied. If venues have been discussed, they are primarily the larger spaces owned by men. The work of club owners is unique, as they also act as club managers and are frequently curators of the music being presented. Club ownership as an occupational category is largely marked as male, with the places and spaces of musical production often seen as being hostile to women. This paper seeks to examine the work of female club owners and reveal the hidden political economy of places and spaces of jazz and blues.
\end{abstract}

KEYWORDS: jazz venues, juke joints, women, gender, work

The histories of the blues and jazz feature dominant narratives that point to specific people, geographies, and spaces from which the genres developed. However, within the narratives of jazz and blues, women are often marginalized, particularly when discussing their importance in roles outside of the conventional categories of musician or muse (usually for a male artist). This essay, focusing on the venues where blues and jazz developed, presents a telescoping history of the role women have played in fostering spaces for blues and jazz performance. As an ethnomusicologist whose research has focused on gender and race in American popular music, my expertise lies in mining the margins of American popular music 
history through methods such as interviews, participant observation, and in this case, archival and historical research. This article represents the beginnings of a larger, multi-sited study that deals with both archives and living informants. For the purposes of this article, my analysis of how women's work has been understood in the blues and jazz worlds begins with a look at the political economy of African American female slaves and eventually focuses on the career of Ada "Bricktop" Smith, one of the most well-known venue owners of the twentieth century. My geographical emphasis, like that of many early jazz and blues histories, lies predominantly in the South, but I expand the traditional narrative of the beginnings of blues and jazz to include women's voices from plantation slavery, postEmancipation juke joints in the rural South, urban lawn parties in New Orleans, and finally to a nationally and globally-known venue owner. At the heart of the article is an attempt to bring the work of women who owned venues in from the margins and to show their vital connection to our understanding of the narrative of the labour that has shaped blues and jazz.

While outside of the scope of this study, an acknowledgement of the critiques to the standard narratives of jazz history need to be addressed. While the "great man" theories propounded by early jazz scholars and critics such as Gunther Schuller (1968) and James Lincoln Collier (1979) have been challenged, the mythologies of jazz (Gebhardt 2012) persist in much of jazz scholarship. This article seeks to extend the critiques of more recent reassessments of jazz history (Johnson 2008, Sublette 2004, and Szwed 2000) to include women club owners.

There is a long history of female club owners, especially clubs that have featured the performance of jazz and blues. Indeed, this history is tied to the spaces owned and curated by women proprietors. Looking at any history of jazz, one will find a description of the first spaces where jazz developed. Some of these spaces were brothels (various histories of jazz describe the music produced in Storyville, the legalized prostitution section of New Orleans). Several of the Storyville brothels were women-owned enterprises (Sanchez 2000). Similarly, blues came about in places known as juke joints, which were and are still often women-owned spaces in the southern United States (see Nardone 2003).

While histories of jazz and blues tend to focus on the musicians and composers of the respective genres, the venues (the spaces and places) where the music is performed have largely gone unstudied. There have been several important studies (for example Pelote 2000 and Berliner 1994) focusing on jazz venues, whereas blues venues have received less attention (see Grazian 2003 and Ryan 2011). The studies listed above, however, predominantly examine the venues from a broad perspective generally ignoring gender (Pelote 2000), or focus on the venues from a musician's or audiences' perspective as opposed to that of the club owner (Berliner 1994). Additionally, if venues have been discussed, they are primarily the larger venues and/or spaces predominantly owned by men such as Birdland (Kronenburg 2012 and Stump 1998) or Café Society (Josephson and Josephson-Trilling 2009).

While these studies are extremely important and provide a launching point for the topic at hand, my aim is to expand our relatively scarce critical knowledge of venue owners in order to understand the economic, racial, and specifically gendered ways in which blues and jazz have been shaped by those who are proprietors.

In Blowing Away the Blues: Performance and Meaning on the New York Jazz Scene, Travis Jackson explores the many facets of the post-1980s jazz scene in New York City. Included in his discussion of the scene is an extensive exploration and theorization of space. Jackson provides a rich literature review of the study of space 
in popular music (including the important work on music scenes contributed by Straw 1991 and Shank 1994) as well as examining how geography (spatiality) plays a role in understanding the jazz scene. Jackson (2012: 53) suggests, "that space, in its geographic and theoretical dimensions, is a crucial component for understanding and conceptualizing jazz". Jackson provides a thorough account of the importance of understanding the differences in the spaces where jazz has been and is performed in New York City. He suggests that the subtle differences in the venues created spaces for different audiences, musicians, and musical styles. Jackson (2012: 5859) explains, "The development of jazz, then, was not simply a function of developments in musical style; it was also a function of developments in the use of urban space". When gender is considered in discussions of space, new interpretations and understandings are revealed. For example, in Gaye Theresa Johnson's Spaces of Conflict, Sounds of Solidarity, she discusses her concept of spatial entitlement. In particular, Johnson (2013: 18) explores the gendered aspects of space: "Space has a significant impact on many aspects of women's lives, from social relationships to economic opportunities". For female proprietors of blues and jazz clubs, the gendered realities of these spaces have gone unexplored.

This essay seeks to examine the work of club owners specifically from the perspective of gender. Women club owners have been a vital part of jazz and blues history and continue to maintain the spaces and places of this music. While oral history, biographies, and autobiographies of women who have owned blues and jazz venues have been written, little has been done to analyze this work through a feminist perspective-in other words, what counts as women's musical labour, and how have ownership and operation by female proprietors been overlooked as spaces of important musical production, consumption, et cetera. in the history of jazz and blues?

\section{The Political Economy of Slavery, Women, and the Narrative of the Blues}

While this article concerns itself primarily with the work of female proprietors of blues and jazz clubs, I begin with a discussion of work among African American female slaves. The political economy of slavery led to the formation of not only the musics discussed in this paper but also the economic realities that many African American women faced in a post-slavery United States. In particular, the story of women-owned clubs and spaces of music-making is bound up in the history of slavery and African American women's work.

Patricia Hill Collins (2000: 44) explains that, "Centering on Black women's experiences produces not only new knowledge but new ways of thinking about such knowledge". While there are studies devoted to examining the lives of African American women slaves in the United States (Jones 1981 and Davis 1985), the lives of women slaves are still underrepresented especially in their role as field slaves. The lack of documentation of African American women's experiences during slavery has led to an absence of African American women's voices from the history of early blues. Why are there very few recordings of women singing field hollers? One reason is that the history of blues and jazz until recently has been written by (predominantly) white male historians, as this statement from the Library of Congress's website on work songs confirms: "Because women's work was not always recognized as labour by male collectors, most work songs have been collected from men." Perhaps the most widely known collector and scholar of this music is Alan Lomax. His recordings of work songs and field hollers from African 
American men in penitentiaries in the South now form the backbone of many histories of the blues (although his work and narrativization of the blues continues to be readdressed and challenged; see Wagner 2009).

The documentation of the work male slaves performed on plantations has overshadowed that of female slaves. The institutional gendered hierarchies ingrained within the early American economy-and the (usually) male scholars writing the histories of this economy-made it such that the work and lives of male slaves were more actively documented especially in the immediate decades after the end of slavery (for example, Wesley 1928). Since the documentation of male slave labour and life was more thorough, it only goes to reason that slave- and postEmancipation-music-making of African American males was also more readily documented. As Gale P. Jackson suggests:

While much of the discussion about African American work songs has been concerned with the experience of men, there is much to be learned from the experience told in the songs and narratives of women.... From their lullabies, to the songs they sang while working in the fields or cooking, women's performances of work are as much about story as about rhythm and pacing (...). (2015: 780).

The documentation of field hollers and work songs by folklorists Alan Lomax, Stetson Kennedy, and Zora Neale Hurston at state prisons of predominantly male African American inmates helped Lomax to foreground the authenticity and origin stories of country blues. The music sung by the inmates came to form the foundation of Lomax's discussion of what built, in particular, the Delta blues. In Lomax's case, this was music performed by men (and a handful of women) away from conventional settings (in some cases brutal prisons). While most of these prisoners were the descendants of former slaves, African American women made up a large percentage of the field slave workforce on plantations and were expected to do the work of both men (picking crops) and women (cooking, cleaning, child rearing). One example of slave women's work comes from historians of slavery in Georgia who note:

Since planters reserved artisan positions for male slaves, the majority of the field hands were female. Slave women constituted nearly 60 percent of the field workforce on coastal plantations.... [Women] prepared fields, planted seeds, cleaned ditches, hoed, plowed, picked cotton, and cut and tied rice stalks. Slave women also cleaned, packaged, and prepared the crops for shipment. (Ramey 2014).

While women were not readily recorded singing field hollers (or work songs, although there is more documentation of women singing work songs; see Jackson 2015), there seems to be little doubt that since women worked in the field they would have sung field hollers. An example of a holler comes from Jackson (2015: 787), who notes that John Moore's mother sang a corn holler when she was in the fields working. However, these references to women singing hollers are scant in the history and documentation of early blues.

Alan Lomax, along with his father John, and Zora Neale Hurston recorded two female inmates in the 1930s in a Florida prison. One of those inmates, Ozella Jones, sang a blues that Alan Lomax titles "I Been a Bad, Bad Girl". In his description of Jones's performance, Lomax (2000: 364) reveals his bias toward what he considered to be the authenticity of her "clear-voiced" singing as opposed to the classic blues 
singers such as Bessie Smith with "their brassbound music-hall throat". Lomax continues to focus on the "holler"-like qualities of Jones's voice:

The blues, sung by an unspoiled singer in the South, sung without the binding restrictions of conventional piano accompaniment or orchestral arrangement, grew up like a wild flowering vine in the woods. Their unpredictable, incalculably tender melody bends and then swings and shivers with the lines like a reed moving in the wind. The blues then show their country origin, their family connection with "the holler." (2000: 364-5).

Lomax clearly heard in Jones's song the "pure" blues, a song and a voice unfettered by the commercial and risqué classic blues of Bessie Smith, Ma Rainey, and the like. However, as Erich Nunn (2015: 81) explains, "Jones's song is (...) based on a commercial recording (Ed Bell's "Bad Boy") (...) and Jones's maintains a nearly word-for-word fidelity to the original". Nunn, in Sounding the Color Line: Music and Race in the Southern Imagination, provides a wonderful analysis of Lomax's search for "authentic" country blues and his ignoring of other blues that did not fit into Lomax's "evolution" of the holler/work song to the "real, pure" blues narrative. While Nunn's analysis of Lomax's work focuses on race, it is also Lomax's adherence to primarily male informants that led to the muting of women's contributions to the blues in general and country blues in particular. One reason for Lomax's exclusion of women is that he foregrounded the labour of men (hammering, chopping, picking), the type of work he viewed as more authentic, and hence overlooked the work of women.

The legacy of slavery directly impacted the labour that African American women could perform. Many African American women went into domestic work (Collins 2000) during the early twentieth century and would not have been hired for labour outside of cleaning house or childcare. The unpaid labour of African American women had a ripple effect in the lives of these workers. Less money meant less buying power in the larger commercial world and this placed African American women in a lower economic and social status than African American men (Collins 2000). Focusing on African American women's political economy via an intersectional approach reveals work performed by women that has been disregarded.

Out of necessity, survival, as well as a love of music some African American women in the South engaged in the business of music entertainment. Owning and operating places such as juke joints and holding lawn parties provided compensation for some women who otherwise would not have had access to income through work conducted in their own homes. As with other African American women's labour, however, female participation in music as performers and especially as venue owners has generally gone unremarked in comparison to studies of African American men in music. Before and after slavery, the work of African American women nevertheless remained a crucial aspect of African American cultural life and of the larger history of the United States.

\section{Juke Joints, Fish Fries, and the Blues}

Club ownership as an occupational category is largely marked as male. In fact, the places and spaces of musical production are often seen as being hostile to women (see for instance Lomax 1993; Pearson 2003). One such place was the juke (or jook) joint: "Jooks were generally black owned and, although landowners expressed some concern about labourers' social activity, their ability to regulate it was 
limited" (Hazzard-Gordon 1990: 67). As a stark example of how unsafe juke joints were considered as spaces for women (at least by historians of the blues), ponder this statement from Alan Lomax in his celebrated The Land Where the Blues Began:

With few exceptions, only women in show business, women of questionable reputation, women who flaunted their loose living, publicly performed the blues - women like Mamie Smith, Bessie Smith and Memphis Minnie. The list isn't very long. These female blues singers toured the black vaudeville circuits or performed in city nightclubs, relaxed in backstage areas out of bounds to the public, in the company of peers. They did not sing in the street or play in jukes and barrooms, where they would inevitably be subjected to sexual advances of every sort, mild to life-threatening. (Lomax 2002: 360).

While this statement by Lomax was written in the late twentieth century, it is recounting work he did in early to the mid-1900s. Yet, the clear assumption by Lomax and others is that juke joints and other hidden spaces were no place for women, especially those performing. Lomax's reticence toward juke joints perhaps lies in the fact that he did not often frequent them during his field trips. Instead, he preferred to speak with the singers at their homes. Since juke joints were "establishments [that] operated on the fringes of the law, and were in effect closed societies to individuals outside of Southern rural African American culture" (Grace 2003: 343) perhaps Lomax could not or did not want to patronize juke joints due to his obvious outsider status. His bias toward "pure," "authentic," and "country" iterations of the blues discussed above may also have influenced this decision. Juke joints, perhaps, did not support his idea of what the blues was supposed to be. It is true that many women were discouraged from going to juke joints and similar venues because of real safety issues as well as perceived religious and moral transgressions that would arise from listening to and participating in blues culture. However, women still readily performed at, danced in, and owned juke joints. One of the first scholars to discuss juke joints was the author and folklorist Zora Neale Hurston (Pearson 2003: 18). Utilizing participant observation, Hurston collected songs, drinking customs, et cetera. while at the same time being a known patron of the spaces (Pearson 2003: 18). Hurston said of the juke (or jook):

It may mean a bawdy house. It may mean a house set apart on public works where men and women dance, drink and gamble (...). Musically speaking, the Jook is the most important place in America. For in its smelly shoddy confines has been born the secular music known as blues. (In Pearson 2003: 18).

However, the juke joint was characterized as a violent space and Hurston perpetuated the more seedy, violent elements of the juke joint in her writing (Pearson 2003: 24). Hurston's and Lomax's characterizations of juke joints as spaces unwelcoming of women have been challenged by oral histories of women who owned and performed in those spaces (Pearson 2003). This is not to say that these spaces were not at times violent or dangerous: the reality lies somewhere in the middle.

In an article for the Arkansas Review, blues scholar Barry Pearson conducted oral histories of several women who performed in or owned juke joints. The women's stories reveal a more nuanced narrative surrounding juke joint culture. Juke joints were a business that women turned to as a means to provide for themselves and their families. As Pearson (2003: 22) explains, "Jooks were not only places to have fun; they were also businesses where food and illegal alcohol were 
sold for a profit. Women ran these establishments with or without the help of a husband or other male enforcer". Former female proprietors of juke joints (and their relatives) explained the necessity of the establishment for their families' livelihoods. The daughter of a juke joint owner, Candy Shines, explained that after her father's death, Shines' mother Mary opened a juke joint in order to support her and her five siblings. Her mother brewed alcohol and her product became so popular that she opened her house as a juke joint where blues musicians provided entertainment (Pearson 2003: 22).

Sandra Hall was another daughter of a female proprietor whose mother ran fish fries every Friday and Saturday night. Hall (in Pearson 2003: 23) explains, "She'd cook up a batch of fish and sell Black Label beer. Back in those days everybody partied in their homes (...). My grandmother played piano, and my sister and I used to sing". Both Hall and Shines were blues singers and they both got their start in their mothers' venues. Juke joints provided spaces for the cultivation of blues especially in the Mississippi Delta and they were also places where women could provide for their families while still working out of (or close to) their homes. Similar establishments were present throughout the South, and they helped to foster the beginnings of blues and jazz.

\section{Lawn Parties, New Orleans, and Jazz}

In an extensive feminist history of women in New Orleans jazz, Sherrie Tucker highlights the contributions, work, and lives of women who participated and helped to shape the spaces and sounds of jazz in New Orleans between 1880 and 1980 in a study called "A Feminist Perspective on New Orleans Jazzwomen." Her study brings to the fore the important but often under-recognized work of women in jazz.

One woman who Tucker researched for the project is Betsy Cole. Highlighting Cole's contribution to the history of jazz in New Orleans as an entrepreneur, Tucker explains that her lawn parties attracted major performers of jazz in the 1910s to the 1920s. While both men and women held lawn parties:

Lawn parties provided certain women who had access to large yards a way to add to their financial well-being without leaving home. The money to be made from lawn parties exceeded what one might make as a laundress or other inhome occupations open to women of color in early twentieth century New Orleans. (Tucker 2004: 68).

Similar to fish fries and juke joints, lawn parties allowed for women to stay in their homes while making an income. Cole's lawn parties in Central City, New Orleans attracted an A-list of early jazz musicians such as Johnny Dodds and Kid Ory (Tucker 2004:70).

For women who were the proprietors of juke joints and fish fries, a knowledge of business, booking entertainment, management, and accounting were necessary to be successful and attract people to the parties. Although the spaces were not as formal as clubs, the knowledge necessary to run them was similar to more standardized spaces of jazz performance. Tucker explains:

The skills required to build a lawn party's reputation included a reputation for hiring bands that would draw regular crowds and repeat customers. A lawn party entrepreneur, therefore, held considerable power in rewarding favorite bands with regular bookings and, therefore, played a significant role in the development of jazz audiences, in facilitating pairings of musicians and 
dancers who inspired one another; to the development of musical practices and therefore to musical sounds, and to the development and maintenance of the local jazz economy. (Tucker 2004: 68).

As musicians began to travel widely and innovations in communication and recording technologies advanced, jazz became a global music (Atkins 2003). Jazz clubs began to open up all over North America, Europe, and beyond. The spread of jazz so quickly from the United States to a global stage highlights the importance of focusing on the necessary migrations that African American musicians (and their music), in particular, had to make in order to find work outside of the South.

The movement of women jazz (and blues) musicians is less well documented than that of their male counterparts. Given the labour market for women in a postslavery America, women's work was often limited to that of the domestic sphere (whether in the employ of a family or in their own families). If African American women did have work outside of their homes, it was limited to only a handful of professions such as beauticians (Baldwin 2014). Women who were involved in the entertainment industry, as suggested by Lomax above, were regarded as less than wholesome, even if they had families. Maintaining one's career as a touring musician was difficult for African Americans, and it was even more difficult for women. Additionally, if African Americans were to take an entrepreneurial role and gain management or ownership status of the places where jazz was performed, their legitimacy as a business owner could be questioned or challenged under the unjust system of legal segregation. What happens to women's work when it moves into traditionally-male territory?

\section{Jazz Club Owners}

The work of a club owner is unique. A club owner is not only a manager (of staff and the venue) but also frequently acts as the curator of the music being presented. In addition to curatorial roles, the club owner must maintain finances as well as the well-being and safety of their clients and musicians. Ada "Bricktop" Smith (whose life and work will be discussed below) explained the varied work of a venue owner:

Running a cabaret was not an easy business. I had to keep my clients happy but make sure they didn't go too far with their antics, watch the waiters so they didn't cheat the customers, make change, tally the receipts, hire and fire the entertainers. Every night there was something new. (Bricktop 1983: 126).

Why then is this space characterized as either a male space or a space where only transgressive women would be found? Given these gendered perceptions of blues and jazz spaces, what does it mean to own and operate such places as a woman? Why is this work not women's work and what happens when a woman does this work?

For many conventional economic studies of U.S. history, the process of owning and operating a place of entertainment (bar, nightclub, et cetera.) does not typically constitute work; or, at least, not important or notable work as compared to other professions. And, while the occupation of musician has more recently been discussed as work (Miller 2008), historically, musicians have not been treated as workers/labourers but as entertainers, a category where their labour is invisible or hidden. Artistic labour is often seen as a magical pursuit. Artists, so the myth goes, do not work - they create. Therefore, the places (at least historically) where blues 
and jazz were performed and produced, were not seen as spaces of physical labour and therefore their owners were not workers either. The club owner, however, like the musician, is working all the time to make a living. This labour is often very difficult and comes at times with little reward. And, ironically, because it is not seen as creative, it is often ignored or viewed dismissively by performers as well as audiences.

Despite the recent focus on the work of jazz musicians, venue owners, and presenters, it is important to note that being a musician has traditionally not been seen as work because of several factors. In the Western art music tradition, priority is often given to the composer instead of the performer. Additionally, the history of jazz put forth by early jazz scholars reinforced this hierarchy by focusing on "great" performers whose talents were seen as effortless. Again, creative labour may be acknowledged, but often the working musician is neglected in favour of the composer or frontman. Additionally, the shifting site of musical production and dissemination (CDs, MP3s, digital files, et cetera.) contributes to an erasure of the work of presenting the performance of music. And finally, shifting venues, from smaller places to larger stadiums, has further covered up the work of venue owners. Therefore, owning and operating a bar/club is not considered to contribute to the work of making music. It is instead an extension of the entertainment already taking place, a hidden labour that enables the similarly hidden labour of the "magic" of performance to take place.

Sociologist and jazz pianist Howard Becker explains how he understood the work of venue owners during his time as a performing musician:

The entrepreneurs who owned and managed these places ([or venues]) had a variety of motives for their activity, but in general the presentation of music was a business activity undertaken for profit. To be profitable, these places had to attract patrons who would pay something to hear the music played, either directly or by buying liquor. (Becker 2004: 20).

In this scheme, Becker implies that club owners are profiting from the real labourers - the musicians-who bring in paying customers. But as ethnomusicologist Tom Greenland suggests, in discussing the work of jazz presenters and venue owners:

[J]azz venue operators and event producers work in conjunction with critics and other commentators whose explanations and evaluations build the reputation and value of - and ultimately the market for-certain artists (...). The most successful presenters, artistically and financially, are those who listen to (and learn from) the audiences, artists, and others they associate with. (Greenland 2016: 83-4).

I now turn to a more detailed exploration of the work of one woman who owned several venues that featured the performance of jazz, Ada "Bricktop" Smith. In examining Bricktop's career through her autobiography,[1] I hope to expand the discussion of this mostly hidden history of jazz and blues, and preview the connections between earlier club owners and more contemporary curators and proprietors of jazz, whom are also women.

While her persona has, at times, overshadowed her labour, I focus on the very real work of owning a venue, reflected in the over forty years Bricktop devoted to the work of club ownership, her experience in multiple roles within the entertainment world, and her candid discussion of her life as a venue owner. 


\section{The House That Bricktop Built}

Bricktop is probably the most celebrated (but perhaps the least studied) club owner in the history of jazz. She was beloved not only because of her striking appearance and her own performance skills (and who she entertained, from F. Scott Fitzgerald to Cole Porter), but also because of how she was able to make her clientele feel at ease and at home all the while running a successful business. Her long career as a club owner highlights many of the considerations women venue owners face in a business that is predominantly male.

Born Ada Smith in 1894 in West Virginia, Smith's father died at a young age and her mother moved her and her three siblings to Chicago so that she could find work. Smith grew up in a multicultural neighbourhood (with Irish, Jewish, Italian, and African American working class families) before the more expansive northern migration of African Americans in the 1920s. Her mother had been born into slavery two years before the Emancipation Proclamation. Smith's (Bricktop 1983: 6) grandmother had "white skin, blue-gray eyes, and black hair and was mostly Scotch-Irish. She was a house slave (...). Mama's maiden name was Thompson, and her father was probably her mother's master". At birth, Smith arrived with red hair, thus her nickname, "Bricktop," which she received when she was a teenager performing in vaudeville.

Bricktop got her start as an entertainer and a singer in "saloons" — her word for cabarets and nightclubs which she uses interchangeably (see Erenberg 1984 for a discussion of the differences between these venues in the United States). Bricktop would sing, dance, and mingle with the clientele. She would eventually join the Theater Owners Booking Association (TOBA) and vaudeville circuits but always returned to saloons. Eventually, she gained a reputation for her ability to give advice about booking talented groups to club owners. This is how she started managing in addition to performing. When Prohibition struck, she was already working for a venue that did not have a liquor license and therefore had a system to sell alcohol without the police finding out. This knowledge helped the club gain an edge on the other speakeasies and they were in need of solid entertainers. During this time, she gained more independence and the bar owners gave her the space to test her hand at management. Bricktop explained:

Barron Wilkins [a club owner] and I got along fine, and pretty soon he started depending on me the way Izzy Levine [another club owner she had worked for previously] (...) had. He asked my advice on music, the scheduling of performers, and lots of other things. When the manager tried to make a pass at me, like he did with all the girls, Barron himself stepped in and told him to stop. (Bricktop 1983: 77).

This description of one of her first managing positions highlights the gendered atmosphere of the entertainment industry. Throughout her recounting of her past experiences, Bricktop subtly addresses the issues women club owners faced in an industry that was dominated by men.

From Chicago, Bricktop travelled around the country and eventually ended up in New York City performing at various venues meeting and gigging with jazz musicians. Jelly Roll Morton accompanied her in Chicago, Los Angeles, and Vancouver, B.C., Canada and he even asked Bricktop (1983: 64) for advice: "[Morton] was still trying to figure out what to do with his life. He couldn't decide whether to be a pimp or a piano player. I told him to do both". While she never 
allowed prostitution in her clubs, she did date pimps and allowed them to patronize her establishments because they protected the entertainment.

She also helped out a young Duke Ellington:

I heard that the kids (...) weren't playing anywhere. They were unemployed and anxious to go to New York. I saw my chance to help them. The outfit we had at Barron's wasn't good, which didn't surprise me. I'd discovered that most nightclub owners had tin ears. I'd complained to Barron every so often, and he'd said that if I ever found another outfit to let him know. So when the Washingtonians became available, I went to bat for them with "Daddy" [Barron]. He hired them immediately, and they joined the other three singers and me at Barron's. (Bricktop 1983: 78).

Eventually, Bricktop's reputation as an entertainer and manager spread and she was asked to become a singer at a club called Le Grand Duc in Paris' Montmartre section. She left the United States in 1924 during the interwar period and helped to define what we now call the Jazz Age. She would eventually manage Le Grand Duc and based on her success there, an owner of another bar suggested that Bricktop open her own. At first, she dismissed the idea because she did not think she knew that much about the business, but then she realized she had accumulated years of experience. She opened a small venue, and when this quickly closed because of licensing issues, she returned to Le Grand Duc to be given the ownership of the club as her bosses wished to retire. On the urging of her clientele, especially Cole Porter, Bricktop opened her own place which she named Bricktop's. This would remain the name of her venues all over the world.

While Bricktop was a seasoned businesswoman, she recounts time and again her experiences as a woman in spaces that were not always safe. Saloons were, for the most part, safe and she felt safe because of pimps (who protected the entertainers and at times suggested talent to the club owners). However, the spaces where alcohol, music, and dance intermingled could also be violent places. She emphasized the violence that took place in several venues where she worked. Three places she worked at were closed following violence: at boxer Jack Johnson's club, Johnson's first wife died from a self-inflicted gunshot; another venue was also closed due to a shooting; and the owner of yet a different venue where Bricktop worked was stabbed to death because he refused to purchase bad liquor during Prohibition. In addition to overt violence, gangsters were often present and were not to be trifled with. Finally, Bricktop got caught up in a bar fight in Vancouver, B.C. and ended up in the hospital with a broken leg. Despite these occurrences, her spaces were known as safe spots where clientele could relax and be themselves. She took great pains and worked hard to make her venues welcoming for both her patrons and her musicians. This meant making the clientele-even the famous ones-aware that fighting was not allowed, as she relates in this anecdote about Ernest Hemingway:

He just wanted to bring people down, and he had a way of doing it, and he was liable to punch you at the same time. He didn't do it in Le Grand Duc-1 had a way of saying, "You can't start a fight in here, I'm a girl". (Bricktop 1983: 98).

In another instance, Bricktop also explains how "being a girl" had its advantages. In discussing the famous jazz guitarist Django Reinhardt and his sometimes unreliable behaviour, Bricktop recalled: 
He called me minou (cat) and when people asked why he worked so well with me and was so temperamental with everyone else, he'd flash a spectacular smile and say, "Because she's a girl and has nice surroundings. I like the people around." (Bricktop 1983: 199).

It is important to note that Bricktop invokes gender in both examples. In drawing attention to the fact that she is female, she is drawing on both conventions of the time-women were to be protected and shielded from such violence (although she herself states that she never shied away from a fight if she was in the right) and drawing attention to her expected protocols - as the proprietor of the venue she had certain rules that her patrons were to follow and respecting her and her space was paramount. Bricktop explained:

It never failed to surprise me that people actually enjoyed hearing me sing. They would stop whatever they were doing to listen. I wasn't temperamental about it, but I did expect my entertainers to be given respect when they were on the floor. If customers were acting up, I'd tell them to keep quiet, that Bricktop's was a place of entertainment, and that if they didn't want to see the show, they should buy a bottle and go home-it was cheaper. That didn't happen very often. I operated a high-class place. (Bricktop 1983: 121).

Patrons returned again and again because of the atmosphere Bricktop created. Not one to shy away from discussions of sexuality, Bricktop explained her rules for engaging with her clientele. As she reveals:

I never fooled around with any of my male clients. I could have. They were sure after me, and I'll say it myself, I was a pretty fast girl, and very well made. I didn't want to be a backstreet mistress to any of those big clients of mine, however, and that's all I could have been. What would we have talked about when we got out of bed? I don't know nothing about polo! (Bricktop 1983: 130).

I include this quote because as an entertainer and club owner who also happens to be a woman, the assumptions-made by men and society in general-of how one rises to a position of authority are sometimes presumed to be based on sexuality as opposed to intellect or other skills. In other words, it is too often assumed that a successful woman has slept her way into prominence. These suggestions are not new to women and are certainly common among entertainers and entrepreneurs. Bound up within the business of venue ownership by female entertainers, as acknowledged by Bricktop, was a woman's sexuality.

Bricktop had to leave Paris because of the Second World War. She went to New York, Mexico City, and then returned to Paris after the war to try her hand at running a saloon in her beloved city. However, the war had changed Paris and despite eventually opening a club, she closed it after only two difficult years and went to Rome. Then she went between Chicago, New York, and back to Rome, eventually returning to New York at the end of her life. She gave up the saloon business after closing her venue in Rome in her seventies but was performing until she was eightyfour. She died in 1984 at the age of eighty-nine. 


\section{Conclusion}

By focusing on female club owners who curated and fostered jazz and blues, I draw attention to a comparatively hidden history of work in the production and consumption of jazz and blues, and narrate how gender plays a significant role in this work. "Work cannot be understood without examining how gender is embedded in all social relations" — this is the epigraph to V. Spike Peterson's (2005: 499) article on "How (the Meaning of) Gender Matters in Political Economy". I end with this quote to emphasize the importance of the embeddedness of gendered discourse within the study of music, but more specifically the study of blues and jazz. Venue owners (whether they be the more informal fish fries, lawn parties, juke joints, or more formal, elite Parisian clubs) provide the spaces where jazz and blues developed. However, female jazz and blues venue owners are faced with a double bind. In discussing the erasure of women (and singing) from early jazz history, Lara Pellegrinelli (2008: 40-1) suggests that "To better establish jazz's credentials as 'serious' art music, historians also divorced the music from its various entertainment contexts". The women discussed in this article were promoting the music while at the same time providing a space and place to nurture the musicians and supply entertainment. At least in the case of Bricktop, entertainment went hand in hand with running her business-she was often the entertainment and she was, in many ways, the business (see Gebhardt 2017, for the role vaudeville and entertainment played in the development of jazz). With this study, I see feminist work and gender analysis in the realm of the political economy, as Petersen (2005: 518) does, "not [as] a digression from nor supplement to conventional accounts [of work]; rather [as] an essential orientation for advancing our theory and practice of political economy". Additionally, examining African American women's work in the music industry through the lens of intersectional discourse, as Collins (2000) suggests, and analyzing the work of women not just as work of the private sphere but as work that intersects with the public sphere, opens up a much more nuanced, inclusive history of blues and jazz with African American women not just on the periphery but at its center.

\section{Endnotes}

[1] Rob Wallace explains, "As Ajay Heble has detailed, such [jazz] autobiographi[es] (...) have been a contested site of identity politics and identity (re)formation. As in musical improvisation where a musician can potentially find her unique 'voice' on an instrument, jazz writing has been an important location of identity formation for improvising musicians" (2009).

\section{References}

\section{Bibliography}

Atkins, E., 2003. Toward a Global History of Jazz. In E. Atkins Ed. Jazz Planet. Jackson: University of Mississippi Press: xi-xxvii.

Baldwin, D., 2014. Making Do: Beauty, Enterprise, and the "Makeover" of Race Womanhood. In Chicago's New Negroes: Modernity, the Great Migration, and Black Urban Life. Chapel Hill: University of North Carolina Press, pp. 53 - 90. 
Becker, H., 2004. Jazz Places. In A. Bennett and R. Peterson Eds. Music Scenes: Local, Translocal, and Virtual. Nashville: Vanderbilt University Press: 17-28.

Berliner, P., 1994. Thinking in Jazz: The Infinite Art of Improvisation. Chicago: University of Chicago Press.

Bricktop, and Haskins, J., 1983. Bricktop. New York: Welcome Rain Publishers.

Collins, P., 2000. Gender, Black Feminism, and Black Political Economy. The ANNALS of the American Academy of Political and Social Science, 568 (1): 41-53.

Collier, J., 1979. The Making of Jazz. New York: Dell.

Davis, A., 1981. Women, race \& class. New York: Random.

Erenberg, L., 1984. Steppin' Out: New York Nightlife and the Transformation of American Culture, 1890-1930. Chicago: University of Chicago Press.

Gebhardt, N. -

2012. When Jazz Was Foreign: Rethinking Jazz History. Jazzforschung, 44: 185-197.

2017. Popular Musicians and Mass Entertainment in American Culture, 1870 1929. Chicago: University of Chicago Press.

Grace, K., 2003. "Juke Joints". In A/cohol and Temperance in Modern History: An International Encyclopedia, Vol. 1, ABC-CLIO: 343.

Grazian, D., 2003. Blue Chicago: The Search for Authenticity in Urban Blues Clubs. Chicago: University of Chicago Press.

Greenland, T., 2016. Jazzing: New York City's Unseen Scene. Champaign: University of Illinois Press.

Jackson, G., 2015. "Rosy, Possum, Morning Star: African American Women's Work and Play Songs": An Excerpt from Put Your Hands on Your Hips and Act Like a Woman: Song, Dance, Black History, and Poetics in Performance. Journal of Black Studies, 46 (8): 773-796.

Jackson, T., 2012. Blowin' the Blues Away: Performance and Meaning on the New York Jazz Scene. Berkeley: University of California Press.

Johnson, G. -

2008. 'Sobre Las Olas': A Mexican Genesis in Borderlands Jazz and the Legacy for Ethnic Studies. Comparative American Studies, 6(3): 225-237.

2013. Spaces of Conflict, Sounds of Solidarity: Music, Race, and Spatial

Entitlement in Los Angeles. Berkeley: University of California Press.

Jones, J., 1985. Labor of Love, Labor of Sorrow: Black Women, Work, and the

Family from Slavery to the Present. New York: Basic Books.

Josephson, B. and T. Trilling-Josephson, 2009. Café Society: The wrong place for the Right people. Champaign: University of Illinois Press.

Kronenburg, R., 2012. Live Architecture: Venues, Stages, and Arenas for Popular Music. New York: Routledge.

Library of Congress. n.d. Traditional Work Songs. https://www.loc.gov/collections/songs-of-america/articles-and-essays/musicalstyles/traditional-and-ethnic/traditional-work-songs/ Accessed: 23 May 2018.

Lomax, A., 1993. The Land Where the Blues Began. New York: Pantheon Books.

Lomax, J. and Lomax, A., 2000. Our Singing Country: Folk Songs and Ballads. Mineola: Dover Publications.

Miller, K., 2008. Working musicians: exploring the rhetorical ties between musical labour and leisure. Leisure Studies, 27 (4): 427-441.

Nardone, J., 2003. Roomful of Blues: Jukejoints and the Cultural Landscape of the Mississippi Delta. Perspectives in Vernacular Architecture, 9: 166-175. 
Nunn, E., 2015. Sounding the Color Line: Music and Race in the Southern Imagination. Athens: University of Georgia Press.

Pearson, B., 2003. Jook Women. Arkansas Review. A Journal of Delta Studies, 34 (1): 18-29.

Pelligrinelli, L., 2008. Separated at "Birth": Singing and the History of Jazz. In N. Rustin and S. Tucker Eds. Big Ears: Listening for Gender in Jazz Studies. Durham: Duke University Press: 31-47.

Pelote, V., 2000. Jazz Venues. In B. Kircher Ed. The Oxford Companion to Jazz. Oxford: Oxford University Press: 722-733.

Peterson, V., 2005. How (the Meaning of) Gender Matters in Political Economy. New Political Economy, 10 (4): 499-521.

Ramey, D., 2014. Slave Women. New Georgia Encyclopedia.

http://www.georgiaencyclopedia.org/articles/history-archaeology/slave-women Accessed: 27 January 2018.

Ryan, J., 2011. Beale Street Blues?: Tourism, Musical Labor, and the Fetishization of Poverty in Blues Discourse. Ethnomusicology, 55 (3): 473-503

Sanchez, T., 2000. The Feminine Side of Bootlegging. Louisiana History, 41(4): 403-433.

Schuller, G., 1968. Early Jazz: Its Roots and Musical Development. Oxford: Oxford University Press.

Shank, B., 1994. Dissonant Identities: The Rock'n'Roll Scene in Austin, Texas. Hanover: Wesleyan University Press.

Straw, W., 1991. Systems of Articulation, Logics of Change: Communities and Scenes in Popular Music. Cultural Studies, 5 (3): 368-88.

Stump, R., 1998. Place and Innovation in Popular Music: The Bebop Revolution in Jazz. Journal of Cultural Geography, 18 (1): 11-34.

Sublette, N., 2004. Cuba and Its Music: From First Drums to the Mambo. Chicago: Chicago Review Press.

Szwed, J., 2000. Jazz 101: A Complete Guide to Learning and Loving Jazz. New York: Hyperion.

Tucker, S., 2004. A Feminist Perspective on New Orleans Jazzwomen: A NOJNHP Research Study. New Orleans Jazz National Historical Park.

Wagner, B., 2009. Disturbing the Peace: Black Culture and the Police Power after Slavery. Cambridge: Harvard University Press.

Wallace, Rob., 2009. Improvisation and Literature: a brief guide. http://www.improvcommunity.ca/sites/improvcommunity.ca/files/research_coll ection/41/Improvisation and Literature.pdf Accessed 2 June 2018.

Wesley, C., 1927. Negro Labor in the United States, 1850-1925: A Study in American Economic History. New York: Vanguard Press. 